www.jmscr.igmpublication.org

Impact Factor 5.84

Index Copernicus Value: 71.58

ISSN (e)-2347-176x ISSN (p) 2455-0450

crossref DOI: _https://dx.doi.org/10.18535/jmscr/v5i10.173

Journal Of Medical Science And Clinical Research

IGM Publication

An Official Publication of IGM Publication

\title{
A Study on Antibodies against Salmonella Typhi and Paratyphi in a Healthy Adults Population at Kulasekharam, Tamil Nadu
}

\author{
Authors \\ Dr Aswathy ${ }^{1}$, Dr Indu.P ${ }^{2}$, Dr Vasantha Babu ${ }^{3}$, Dr Umapathy ${ }^{4}$ \\ ${ }^{1}$ Consultant Microbiologist, KIMS Hospital, Thiruvananthapuram, Kerala \\ ${ }^{2}$ Professor and Head of the Dept. of Microbiology, Sree Mookambika Institute of Medical Sciences, \\ Kulasekharam \\ ${ }^{3,4}$ Professor of Microbiology, SMIMS
}

\begin{abstract}
Enteric fever remain as an important public health problem globally and it is a major cause of morbidity in the developing world. Typhoid fever is caused by Salmonella typhicc and a less severe disease, paratyphoid fever is caused by Salmonella paratyphi A, B and $C$. widal test is a tube agglutination test done in most of the clinical laboratories used for the diagnosis of enteric fever. Antibodies against $O$ antigen of Salmonella typhi and $H$ antigens of Salmonella typhi and paratyphi $A$ and $B$ are defeated and antibody titre is measured by doing this test in cases with clinical suspicion. In India where enteric fever is endemic, the serum of a proportion of healthy people contain antibodies capable of reacting to a variable titre, in widal test. A study was conducted by the Department of Microbiology at Sri Mookambika Institute of Medical Sciences (SMIMS), Kulasekharam, Tamil Nadu during a period of one year from November 2011 to October 2012 to find out the basal antibody titres against $O$ and $H$ antigens of Salmonella typhi and $A H$ and $B H$ antigens of Salmonella paratyphi $A$ and $B$ respectively in a healthy population between the age group of 15 to 45 years of age in the local area. A proportion of Medical and paramedical Staff and students of the Institute were also included in the Study. A total number of 250 samples of blood collected from the persons in the study group and widal test was performed in the clinical Microbiology laboratory with the serum seperatated from the samples after centrifugation. Of the 250 sera tested, 137 (54.8\%) showed agglutination in the dilution of <1:20, for Salmonella O antibody, $176(70.4 \%)$ showed $H$ antibody titre in 1:20 dilution, 234 (93.6\%) and 232 (92.8\%) showed H antibodytitre in 1:20 dilution for Salmonella paratyphi A and B respectively. None of the samples showed antibody titres above 1:80 for TO, 1:160 for TH, AH and BH antibodies. The cut off limit was similar to the values reported from many other students conducted in different endemic areas in India.

Keywords: Typhoid fever, paratyphoid fever, widal test, Antibody titre, Salmonella typhi and Salmonella paratyphi.
\end{abstract}

\section{Introduction}

Typhoid and paratyphoid fever collectively known as enteric fever occur as an acute, life threatening febrile illness with classical symptoms of gradual onset of sustained fever, child, hepatosplenomegaly and abdominal pain, diarrhoea or constipation headache and relative bradycardia. Without effective treatment, case fatality rate is 
$10-30 \%$. Mortality rate may bereduced to $1-4 \%$ by early diagnosis and administration of appropriate antibiotic therapy. The highest incidence is seen in Asia, particularly in the South- Central and SouthEastern regions where an estaimated rate of 100 cases / 100000 population occur each year. The improvement in sanitary conditions and health care is thought to be a key factor in reducting the incidence. Typhoid fever is endemic in India too affecting about 3 lakh people in a year of which 735 deaths occur annually.

In developing countries the widal test (Tube agglutination Test) is the serological test used for the diagnosis of typhoid fever because of the lack of culture facilities in many laboratories like Sudan, normal healthy people have a high antibody titre against Salmonella typhi and there the widal test is interrupted against this back ground. In our country where Typhoid is endemic, the serum of a proportion of persons contain antibodies capable of reacting to a variable titre in widal test. The present study is to find out the basal antibody tutres against different antigens of Salmonella typhi and Salmonella paratyphi $\mathrm{A}$ and $\mathrm{B}$ in a random healthy adult population, which will be useful in the interpretation of widal test in Typhoid cases.

\section{Materials and Methods}

Study design: Descriptive study

Study population: Healthy adults from local area, Doctors, Laboratory technicians and medical and paramedical students.

Study period: 1 year (November 2011 to October 2012)

Sample size: 250 serum samples

Age group: $15-45$ years

Inclusion criteria: Healthy adults

Exclusion criteria: patients with fever $>7$ days patients who have taken TAB vaccine Patients with past H/o typhoid Patients diagnosed as Typhoid fever cases

\section{Collection of sample}

Blood samples was collected by venepuncture under aseptic precuations. The site was cleaned with betadine and then by surgical spirit and $5 \mathrm{ml}$ of blood collected from each person from the cubital vein. Clean transferred to a dry, sterile test titre. Serum was separated from the sample by contriffugation and stored in the Eppendorf bottles.

\section{Widal test Procedure}

Test tubes were arranged in A rows Each row consists of 6 test tubes. 6 serial dilutions from $1 / 20$ to $1 / 640$ was made using normal saline $(1000$ microL) in all test tubes from $1 / 40$ to $1 / 640$ and $11900 \mu \mathrm{l}$ of saline in $1 / 20$ dilution test tube. To the $1 / 20$ (first) test tube $100 \mu \mathrm{l}$ serum sample was added, mixed and $1000 \mu \mathrm{l}$ was transferred to the next (second) test tube of $1 / 40$ dilution. This is again mixed and $1000 \mu \mathrm{l}$ transferred to the third $1 / 80$ dilution test tube. This procedure was thus followed till the last test tube of 1/640 dilutions from which $1000 \mu \mathrm{l}$ was discarded. To each series of dilutions $500 \mu \mathrm{l}$ of antigen $\mathrm{O}$ antigen and $\mathrm{H}$ antigen of Salmonella typhi and $\mathrm{H}$ antigens of Salmonella paratyphi A and B were added and mixed well in a cyclomixer and incubated at $370 \mathrm{C}$ for 18 hours. A control for each antigen consisting of $1000 \mu \mathrm{l}$ saline and a drop of antigen thoroughly mixed was also kept. (antigen control. The maximum dilution in which agglutination occurs was noted. This was the titure value $\mathrm{O}$ agglutination was seen as coarse chalky granular clumps and $\mathrm{H}$ agglutination as large loose fluffy clumps.

\section{Results}

A total number of 250 samples of blood collected from healthy persons with age group between 15 to 45 years residing in the local area surrounding Sree Mookambika Institute of medical Sciences, Kulasekharam, Tamil Nadu, serum was separated by centrifugation from each sample when it was brought to the microbiology laboratory immediately after collection. Widal test was performed using the antigen kit supplied by SPAN diagnostics. Antibodies were tested against the $\mathrm{O}$ antigen and $\mathrm{H}$ antigen of Salmonella typhi and $\mathrm{H}$ antigens of paratyphi A and B. 
Table I : Gender Distribution

\begin{tabular}{|l|c|}
\hline Gender & No. of percentage \\
\hline Male & $106(42.4 \%)$ \\
\hline Female & $144(57.6 \%)$ \\
\hline Total & $250(100 \%)$ \\
\hline
\end{tabular}

Table 2: Age distribution

\begin{tabular}{|l|c|}
\hline Age & No. of percentage \\
\hline $10-15 \mathrm{yrs}$ & $84(33.6 \%)$ \\
\hline $26-30 \mathrm{yrs}$ & $53921.2 \%)$ \\
\hline $36-45 \mathrm{yrs}$ & $113(45.2 \%)$ \\
\hline Total & $100 \%$ \\
\hline
\end{tabular}

Table 3 : Type of drinking water

\begin{tabular}{|l|c|}
\hline Drinking water type & No of persons \\
\hline Persons used water & $186(74.4 \%)$ \\
\hline Persons used pipe water & $64(25.6 \%)$ \\
\hline Total & $250(100 \%)$ \\
\hline
\end{tabular}

Table 4: History of travel to endemic area

\begin{tabular}{|l|c|}
\hline Study population & No. of persons \\
\hline Persons who travel & $22(8.8 \%)$ \\
\hline Persons not travelled & $228(91.2 \%)$ \\
\hline Total & $250(100 \%)$ \\
\hline
\end{tabular}

Table 5: Distribution of $\mathrm{O}, \mathrm{H}, \mathrm{AH}, \mathrm{BH}$ antibody titre

\begin{tabular}{|l|c|c|c|c|c|}
\hline Sl. No. & Serum Dilutions & $\begin{array}{c}\text { O antibody No. } \\
2 \%\end{array}$ & $\begin{array}{c}\text { H antibody No } \\
\%\end{array}$ & $\begin{array}{c}\text { AH } \\
\text { No \& } \%\end{array}$ & BH No \& $\%$ \\
\hline 1 & $<1: 20$ & $137(54.8 \%)$ & $176(70.4 \%)$ & $234(93.4 \%)$ & $232(82.8 \%)$ \\
\hline 2 & $1: 20$ & $76(30.4 \%)$ & $43(17.2 \%)$ & $9(3.6 \%)$ & $10(4 \%)$ \\
\hline 3 & $1: 40$ & $31(12.4 \%)$ & $26(10.4 \%)$ & $7(2.8 \%)$ & $8(3.2 \%)$ \\
\hline 4 & $1: 80$ & $6(2.4 \%)$ & $5(2 \%)$ & $0(0 \%)$ & $0(0 \%)$ \\
\hline 5 & $1: 160$ & $0(0 \%)$ & $0(0 \%)$ & $0(0 \%)$ & $0(0 \%)$ \\
\hline 6 & $1 ; 320$ & $0(0 \%)$ & $0(0 \%)$ & $0(0 \%)$ & $0(0 \%)$ \\
\hline 7 & $1: 640$ & $0(0 \%)$ & $0(0 \%)$ & $0(0 \%)$ & $0(0 \%)$ \\
\hline & Total & $250(100 \%)$ & $250(100 \%)$ & $250(100 \%)$ & $250(100 \%)$ \\
\hline
\end{tabular}

In the study group, maximum number of persons comes under 36-45 years of age, (45.2\%) followed by $15-25$ year age group (33.6\%) and 26-30 year age group (21.2\%). Of the total number of 250 healthy adults in the study group, $228(91.2 \%)$ did not travel to endemic areas only $(22(8.8 \%)$ did give a history of travel to endemic areas. Majority of the population was static. They had not travelled out of the area. In the present study population, females were more than the males. Females were more than the males. Females accounting for $57.6 \%$ and males $42.4 \%$.

Majority of the persons used well water for drinking purpose $(74.4 \%)$. Rest of the $25.6 \%$ used for drink pipe water. There is no relation between drinking water. Source and To and TH antibody titre of Salmovella typhi since the $p$ value is not statistically significant. Of the 186 people who used well water, $55.9 \%$ had to antibody titre $<1: 20$, $29.6 \%$ had a titre of $1: 20,11.8 \%$ had a titre of $1: 40$ and $2.7 \%$ had 1:80 titre. For the 54 subjects in the study who used pipe water, $50 \%$ showed $<1: 20,34.4 \%$. Showed a titre of $1: 20,14.1 \%$ showed 1:40, and just 1 person showed 1:80 dilution. As the percentage values do not show drastic differences a significant relation could not be obtained. AH antibody is seen in <1:20 dilution for 170 samples $(91.4 \%)$ collected from persons who used well water for drinking purpose while 63 samples (98.4\%) from the persons who used the pipe water supply for drinking purpose. No one above 1:40 and 1:20 for well water and pipe water respectively. In the case of Salmonella paratyphi $\mathrm{BH}$ antibody titre, 2 (3\%) had 1:20 dilution, and no one had 1;40 to 1:20 dilution, and no one 1:40 to 1:640 dilutions. While testing from $\mathrm{BH}$ antibody, of the 186 persons who used well water for drinking purpose, 170 (91.4\%) had antibody titre in $<1: 20$ dilution $8(4: 3 \%)$ had 1:20 dilution, $8(43 \%)$ had agglutination in 1:40 dilution. No one was detected in 1:80 dilution to 1:640 dilutions.

\section{Salmonella typhi $O$ antibody titre}

Of the 250 sera tested, 137 (54.8\%) had a dilution of $<1: 20,76(30.4 \%)$ had a dilution of $1: 20,31$ $(12.4 \%)$ had a titre of $1: 40$ and only 6 samples yielded 1:80 dilution which from $2.4 \%$ of the total study population. None of them gave 1:160, 1;320, 1:640 titre. 


\section{Salmonella typhi $\mathrm{H}$ antibody titre}

$176 \quad(70.4 \% 0$ serum samples were having agglutination in $<1: 20$ dilution of $\mathrm{H}$ antibody titre. $43917.2 \%$ ) were in 1:20 $\mathrm{H}$ antibody titre level. $26(10.4 \%)$ of the samples had antibody titre in 1:40 dilution. Only 5 (2\%) accounting for 1:80 dilution. There were no case in 1:160, 1:320, 1:640 dilutions for $\mathrm{H}$ antibody titre.

\section{Salmonella paratyphi AH antibody titre}

$234(93.6 \%)$ out of 250 serum samples tested were in $<1: 20$ dilution. While $9(3.6 \%)$ had $1: 20$ and $7(2.8 \%)$ were in 1:40 dilutions for $\mathrm{AH}$ antibody. No samples had antibody titre in 1:160, 1:3230 and 1:640 dilutions Salmonella paratyphi $\mathrm{BH}$ antibody titre.

232 samples $(92.8 \%)$ had $\mathrm{BH}$ antibody titre in $<1: 20$ dilution 10 samples (4\%) in 1:20, 8 amples (3.2\%) in 1:40 levels. There were no samples giving agglutination titre 1:80, 1:160, 1:320 and 1:640 for BH antibody.

\section{Discussion}

Typhoid fever occur in all parts of the world, where water supper and sanitation are substandard. In India, it continues to be a major endemic disease. The different clinical presentations of the disease due to variable virulence and dosage of the bacilli and the differences in the resistance and immunity of the host make the diagnosis of enteric fever difficult. The isolation of Salmonella typhi from blood provides definite evidence of infection. But it is usually not feasible in clinical practice for one reason or the other to submit blood for culture in the first week of illness and before any antibodies have been administered. Widal test is almost always advised to substantiate clinical suspicion. It is cheap, easy to perform and is repdocible so commonly used in our country.

In any patient with history of prolonged fever, widal test is almost always performed. The serum of a proportion of patients in endemic counties contain antibodies against salmonella typhi and Salmonella paratyphi which can be detected in the widal test but usually the titres are low. Therefore the diagnostic titre for any population has to be ascertained taking into consideration the antibody prevalence against the Salmonella antigents.

In the present study, only 6 samples out of 250 total samples showed $\mathrm{O}$ antibody titre in 1:80 and none above 1:80. So also $\mathrm{H}, \mathrm{AH}$ and $\mathrm{BH}$ were not obtained in titres $>1: 160$. There were 5 samples which gave 1:80 for $\mathrm{H}$ antibody of Salmonella typhi but both $\mathrm{AH}$ and $\mathrm{BH}$ antibodies were less than 1:80, in fact in the $<1: 20$ to $1: 40$ range. Since none of the values were positive as per the proposed cut off value of $>1: 100$ for To and $>1: 200$ for $\mathrm{TH}$ endemic area and drinking water supply was unusable to be ascertained. As India is an endemic country, the cut off limit for Salmonella enteriuca antibodies should be found out as per the study conducted on its apparently healthy population. None of the studied, population male or female had ' $\mathrm{O}$ ' antibody level above the proposed cut off value of 1:100. Therefore 1:100 cut off limit can be taken as the valid level even in Kulasekharam. In the same way, no one either male or female had ' $H$ ' antibody tire of Salmonella typhi above the proposed cut off value of 1:200. Therefore this can be taken as the valid cut off limit for TH antibody in Kulasekharam. So also is the scenario with $\mathrm{AH}$ and $\mathrm{BH}$ antibodies. None of the population wader study had a level above 1:200. Therefore 1:200 can be taken as a valid cut off limit in Kulasekharam, Tamil Nadu as is the case is rest of India.

Wilson and Miles concluded that in a patient without history of TAB vaccination or of previous enteric infection, living in a country in which the disease is at a low endemic level a titre of 12:100 for $\mathrm{O}$ antibodies and 1:50 for $\mathrm{H}$ antibodies offer a string presumptive evidence of infection. Obviously these criteria area for the the population of England and do not hold good for India. The minimum diagnostic titre arrived at by Singh and Nair, Modi, and vaidya in their study were 1:50 for Salmonella typhi $\mathrm{O}$ and $\mathrm{H}$ antigens of S. typhi, paratyphi A and B. Studies conducted by Steven $\mathrm{A}$ and Chow $\mathrm{CD}$ also suggested the 
minimum diagnostic titres as $>1: 50$ for To and $\mathrm{TH}$ antigens. Following a study at Singapore, chew S.K. have suggested $1: 40$ as the minimum diagnostic titre for Salmonella typhi $\mathrm{O}$ and $\mathrm{H}$ antibodies was recommended by Saha in Bangladesh children. Theivanesan $\mathrm{V}$ had suggested a minimum diagnostic titre of 1:120 following a study in Srilanka.

Many studies carrier out by many authors. Such as Rasaily et al, Clegg A, Kulkarni, Pang T, Mohamed I, Abraham J etc. recommended a minimum, diagnostic titre of 1:320 was reported by El-Shafees.

Similarly a study in Vietnam found that using widal test cut off titres of $>1: 200$ for $\mathrm{O}$ agglutinin or $>1: 100$ for $\mathrm{H}$ agglutination correct diagnosis was established in $74 \%$ of the blood culture positive cases of typhoid fever. Other studies also reported that a cut off value of anti $\mathrm{O}$ titre> $1 ; 160$ using widal agglutination test was more predictive of salmonella enterica infection. It also appered that anti-H titre was more useful than anti $\mathrm{O}$ titre. In interpreting the results of the widal test, the antibody titres obtained are compared with the titres which had been noted for the population who at the time of examination were febrile. It has been suggested that in a case of fever, the titre would not be a significant indication of active infection unless it was such as was not expected to be present in more than $5 \%$ of the normal population.

It can be said that in unhygienic conditions, improper sanitation and sewage disposal the communities are persistently in contact with infecting agents. So endemicity of Salmonella infection give rise to high normal antibody titres against different Salmonella group of organisms. In developed countries where water supplies are well treated with disinfectants and proper sewage disposal carried out, the normal antibody titres are found to be lower compared to those of the endemic areas. The other probable reason for high normal antibody titres could be due to nonspecific lymphoid tissue stimulation by Salmonella group of organisms other than the infecting agent.

\section{Summary}

Enteric fever caused by Salmonella typhi and Salmonella paratyphi occur in all parts of the world, where water supply and sanitation are substandard. In India, it continues to be a major endemic disease.

Widal test is a serological test that is most frequently used to diagnose enteric fever, so that appropriate e treatment can be instituted. This is because without effective treatment, typhoid fever has a case fatality of 10 to $30 \%$. This number of drastically reduced to 1 to $4 \%$ in those receiving appropriate therapy. The aim of the present study is to find out the minimum diagnostic titre of $\mathrm{O}$ antibody of S.typhi and S. Paratyphi A and H, AH and $\mathrm{BH}$ antibodies of S. Typhi, S. paratyphi A and S. paratyphi B respectively in a healthy adult population within the age group between 1545 years.

A total of 250 serum samples were tested after collecting blood samples from subjects in the local area and medical and paramedical staff and students. The study showed that none of the values were positive as per the current proposed cut off value of >1:100 for TO and >1:200 for TH antibodies in India. Therefore 1:100 and 1:200 can be taken as the valid level for $\mathrm{O}$ antibody and $\mathrm{H}$ antibody titres respectively in Kulasekharam as it is shown by similar studies conducted in different parts of India.

\section{Conclusion}

The diagnostic test for enteric fever the widal test which was developed by F.widal in1896, still continues to be an universally accepted one. The test is been done as a routine serological test in all the clinical microbiology laboratories all over India where enteric fever is endemic. This is one of the important laboratory investigations advised by the clinician/physician in all cases of pyrexia of unknown origin. The widal test will be positive during the second week of febrile illness. Since the antibody for salmonella antigens will be in significant titre during this period. For the interpretation of widal test result, it is mandatory 
to know the endemic titre in that area. The cut of limit for $\mathrm{O}$ antibody of salmonella typhi is $>1: 100$ and for $\mathrm{H}$ antibodies of salmonella typhi and paratyphi A and B are >1:200 in India. Our study indicates that this proposed cut of limit is valid from the value we obtained from the observations after testing statistically significant sample size from healthy adult population at kulasekharam, Tamil Nadu.

\section{Conflicts of interest}

There are no conflicts of interest

\section{Acknowledgement}

I owe my sincere thanks to Dr. rema v. Nair, Director, Sree Mookambika Institute of Medical Sciences, Kulasekharam, Tamil Nadu and dr. velayudhan Pillai Chairman of the Institute for allowing me to avail the facilities needed for the study.

I am extremely thankful to Dr. Padma Kumar, Principal, SMIMS for granting me permission to conduct the study.

I express my gratitude to dr. VasanthaBabu and Dr. Umapathy, Professors of the Dept. of Microbiology at SMIMS for their valuable suggestions and guidance to perform the study.

I am extremely grateful to Dr. Indu .P. Professor and Head of the Dept. of Microbiology, SMIMS for her guidance and encouragment throughout the study.

I am thankful to Dr. Lancy .J. Additional Professor of Microbiology, Govt. Medical College, Thiruvananthapuram, Kerala for the help in preparing the manuscript.

\section{References}

1. Cherian .T, Sridharan.G, Mohandas .v, Jacob John T, Prevalence of Salmonella typhi $\mathrm{O}$ and $\mathrm{H}$ antibodies in the serum of infants asnd preschool children Indian Paediatrics, 1990; vol. 27:293-294.

2. A. Rattan, V. Maheswari, NK Maheswari et al. Application of modified widal test in specific diagnosis of enteric fever. Indian Peadiatrics 1990 vol:27: 295-297.

3. forSyth JRL; Typhoid and paratyphoid fever. topley and wilson's Microbiology and Microbial Infections 1998. 9th edition Vol:3 :459-479.

4. Sanjay S., Bhavesh P, Chitnis DS, 100 years of widal test and its reappraisal in an endemic area. Indian J Med. Res. 1997:vol.105:53-57.

5. El-Shafie $\mathrm{S}$ : the widal test in a normal healthy populatiojn in the Sudan East African Med. J. 1991. April : 68 (4) 266-69.

6. Mandell LG \&Benett's Principles and practice of Infectious diseases.

7. Crump JA, Luby SP, Mintz ED. The global burden of typhoid fever. WHO Bulletin : 2004 : 82:343-53.

8. Olopoenia LA, king LA; widal agglutination test - 100 years later, Post Graduate medical Journal 2000; 76:80-84.

9. R. Rasaily, P. Dutta, MR Saha. Value of a single widal test in the dianosis of Typhoid fever, Indian J. Med. Res. 1993:97:104-7.

10. PJ Joshi, A Samuel, DS Dongre et al. Normal agglutinins against Enteric group of organisms in healthy subjects. Indian Journal of Medical Sciences. 1998:

11. T. Pang, SD Pudecheary. Sginificance and value of the widal test in the diagnosis of typhoid fever in an endemic area. J. Clin. Path.1983; 4:36-37.

12. KB Tanyigna, JA Ayeni. Antibody levels to Salmonella typhi and paratyphi in Nigerians. East Afr. Med. J 1999; 11: 6235.

13. EH Frtrnpong, feglo P Essel, M Ahun. Determination of Diagnostic widaltitres in Kumari, Ghana.West Afr. J. Med. 2000; 19:34-38. 